\title{
Aprotic lithium air batteries with oxygen-selective membranes
}

\author{
Asad A. Naqvi ${ }^{1} \cdot$ Awan Zahoor $^{2} \cdot$ Asif Ahmed Shaikh $^{3} \cdot$ Faaz Ahmed Butt $^{4} \cdot$ Faizan Raza $^{5} \cdot$ Inam Ul Ahad ${ }^{6} \mathbb{D}$
}

Received: 31 July 2021 / Accepted: 5 November 2021 / Published online: 24 January 2022

(C) The Author(s) 2022

\begin{abstract}
Rechargeable batteries have gained a lot of interests due to rising trend of electric vehicles to control greenhouse gases emissions. Among all type of rechargeable batteries, lithium air battery (LAB) provides an optimal solution, owing to its high specific energy of $11,140 \mathrm{Wh} / \mathrm{kg}$ comparable to that of gasoline $12,700 \mathrm{Wh} / \mathrm{kg}$. However, LABs are not widely commercialized yet due to the reactivity of the lithium anode with the components of ambient air such as moisture and carbon dioxide. To address this challenge, it is important to understand the effects of moisture on the electrochemical performance of LAB. In this review, the effects of ambient air on the electrochemical performance of LAB have been discussed. The literature on the deterioration in the battery capacity and cyclability due to operation in ambient environment and degradation of lithium anode due to exothermic reaction between lithium and water is reviewed and explained. The effects of using oxygen-selective membrane (OSM) to block moisture and $\mathrm{CO}_{2}$ contamination has also been discussed, along with suitable materials that can act as OSM. It is concluded that the utilization of OSM can not only make the safer operation of LAB in ambient air but could also enhance the electrochemical performance of LAB. Future direction of the research work required to address the associated challenges is also provided.
\end{abstract}

Keywords Lithium air battery $\cdot$ Energy storage $\cdot$ Oxygen selective membrane $\cdot$ Hydrophobic membrane

\section{Introduction}

Global warming is one of the major problems in the world due to which earth temperature is increasing continuously [1]. The main reason of the global warming is carbon emissions [2]. The amount of carbon dioxide in the beginning of 2019 was around $407 \mathrm{ppm}$ which was $277 \mathrm{ppm}$ in 1750 in a preindustrial era [3].The contribution of transport sector in

Inam Ul Ahad

inamul.ahad@dcu.ie

1 Department of Mechanical Engineering, NED University of Engineering and Technology, Karachi, Pakistan

2 Department of Food Engineering, NED University of Engineering and Technology, Karachi, Pakistan

3 Department of Environmental Engineering, NED University of Engineering and Technology, Karachi, Pakistan

4 Department of Materials Engineering, NED University of Engineering and Technology, Karachi, Pakistan

5 Department of Chemical Engineering, NED University of Engineering and Technology, Karachi, Pakistan

6 School of Mechanical and Manufacturing Engineering, Dublin City University, Dublin, Ireland global carbon dioxide emissions is around 24\% [4] and [5] because of dependence on fossil fuel. On average, around $150 \mathrm{~g}$ per $\mathrm{km}$ of $\mathrm{CO}_{2}$ is produced by conventional fossil fuelbased vehicles [6] which are capable to produce the tremendous amount of carbon dioxide. Therefore, it is important to look for an alternate of the fossil fuel-based transportation. The reliability and cost effectiveness are the main aspects of the alternative. Electric vehicles are considered as an alternate of fossil fuel-based transportation [7]. Electric vehicles normally utilize fuel cell or rechargeable batteries [8-10]. The use of fuel cell is an expensive option as it uses pure hydrogen, which requires costly production processes [11]. So, the use of batteries in electric vehicle is the most economic and effective option.

Batteries are commonly used for storage of electrical energy in the form of chemical energy. During discharging of battery, chemical energy is transformed into electrical energy thus providing an electric current. While, during charging, electrical energy is supplied to battery which ultimately stores as chemical energy. There are numerous commercial battery technologies available including lead acid battery, nickel cadmium battery and lithium-ion battery. Among all available battery technologies, lithium-ion 
batteries have achieved a lot of consideration as energy storage device in hybrid and electric vehicles [12] and mostly all the manufacturers of such types of vehicles are using lithium-ion batteries [13] due to their higher energy density as compared to the other available and commercial battery technologies. But still, energy density of lithium-ion battery is very much low as compared to gasoline. This means that it is not a suitable candidate for replacement of gasoline. So, it is desired to look for an alternate energy storage device [14]. Metal-air batteries are studied as the alternate of lithiumion batteries and a lot of research has been conducted on metal-air batteries [15-25]. Among all types of metal-air batteries, LAB is the suitable candidate to replace the fossil fuel-based transportation in future due to its high theoretical energy density of $11,140 \mathrm{Wh} / \mathrm{kg}$ among the other types of batteries and is also comparable to the energy density of the gasoline which is $12,700 \mathrm{Wh} / \mathrm{kg}$ [26]. The energy density of different types of batteries is summarized in Table 1. The practical energy density of lithium air battery is ten times as that of lithium-ion battery [27]. Therefore, for complete shifting from fossil fuel-based transportation to electrical vehicles, a lot of research in lithium air batteries is required to make the operation of electric vehicles cheap and reliable.

There is a growing interest among researchers to address the challenges in operation of LAB; however, very few review articles have been reported recently explaining the technical problems in LAB function in ambient environment and solutions to avoid these. In this review paper, the fundamental operating principle of LABs has been explained and associated factors limiting the battery performance have been presented. Ambient air, moisture and $\mathrm{CO}_{2}$ interact with the lithium anode and discharge products forming $\mathrm{LiOH}$ and $\mathrm{Li}_{2} \mathrm{CO}_{3}$. These compounds are found to be difficult to decompose thus results in low battery life and efficiency. The solution of such problem is the use of membrane which blocks the moisture and $\mathrm{CO}_{2}$ to enter into the battery and allows only oxygen to enter. Recent studies on avoidance of moisture and $\mathrm{CO}_{2}$ contamination on lithium electrodes

Table 1 Theoretical energy density of different batteries and gasoline

\begin{tabular}{lll}
\hline Battery type & Energy density & Reference \\
\hline Lead acid & $123 \mathrm{Wh} / \mathrm{kg}$ & {$[28]$} \\
Lithium ion & $250 \mathrm{Wh} / \mathrm{kg}$ & {$[29]$} \\
Zinc-oxygen & $1084 \mathrm{Wh} / \mathrm{kg}$ & {$[15]$} \\
Sodium-oxygen & $1605 \mathrm{Wh} / \mathrm{kg}$ & {$[30]$} \\
Magnesium-oxygen & $6800 \mathrm{Wh} / \mathrm{kg}$ & {$[31]$} \\
Aluminum-oxygen & $8100 \mathrm{Wh} / \mathrm{kg}$ & {$[32]$} \\
Lithium-sulfur & $2600 \mathrm{Wh} / \mathrm{kg}$ & {$[33]$} \\
Lithium-air & $11,140 \mathrm{Wh} / \mathrm{kg}$ & {$[34]$} \\
Gasoline & $12,700 \mathrm{Wh} / \mathrm{kg}$ & {$[26]$} \\
\hline
\end{tabular}

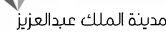

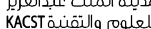

have been reviewed to indicate the future directions of LABs technology.

\section{Working principle of lithium air batteries}

Lithium air batteries are composed of pure lithium anode, carbon-based oxygen cathode and an organic electrolyte. Upon discharging lithium and oxygen combines electrochemically and form discharge product $\mathrm{Li}_{2} \mathrm{O}$ or $\mathrm{Li}_{2} \mathrm{O}_{2}$ depending on the type of oxidation-reduction reaction (ORR) [35]. Upon charging, discharge product decomposes and gives back lithium and oxygen back to the atmosphere. The schematic of lithium air battery working principle is presented in Fig. 1. Abraham and Jiang [36] first reported the non-aqueous lithium oxygen battery in 1996. Afterwards, many research groups conducted the research on lithium air batteries [37-44]. Awan, Christy, Hwang and Nahm [45], reported following four types of lithium air batteries on the basis of electrolyte:

i. Non-aqueous/aprotic electrolyte LAB

ii. Aqueous electrolyte LAB

iii. Solid-state electrolyte LAB

iv. Hybrid electrolyte LAB (combination of all three).

All of the four abovementioned batteries have their separate challenges. In the non-aqueous/aprotic electrolyte $\mathrm{LAB}$, the reaction of moisture and $\mathrm{CO}_{2}$ with the lithium anode results in the decrement of battery capacity, cyclability and efficiency [46-49]. Also, for non-aqueous electrolyte LAB, the discharge product is insoluble in aprotic electrolyte thus causing the clogging of cathode [49-52].

In aqueous electrolyte $\mathrm{LAB}$, discharge product is soluble in electrolyte but their specific energy is around 30\% lower than that of aprotic one [35, 53-55]. The production of Solid

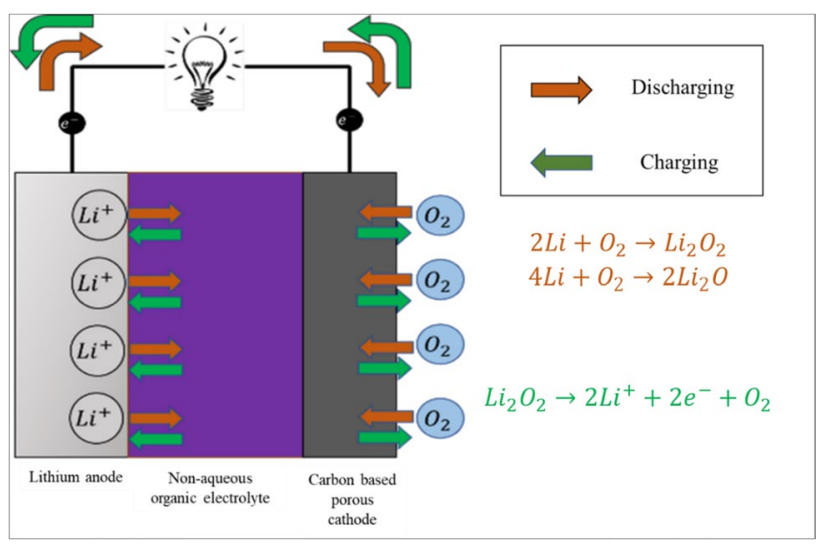

Fig. 1 Aprotic LAB working principle 
electrolyte for LAB normally occurs at high temperature of around $800{ }^{\circ} \mathrm{C}[56,57]$ which ultimately decreases the net energy density of the battery. Also, the conductivity of solid electrolyte LAB is around $1.92 \times 10^{-4} \mathrm{~S} / \mathrm{cm}$ at room temperature and is increased by increasing the temperature [58].

The above-mentioned issues need to overcome in order to commercialize lithium air batteries. The operation of lithium air battery is similar to that of a fuel cell. During the discharge operation, lithium anode gives lithium ions which are dissolved in the electrolyte and then travel towards the carbon cathode where joining of lithium ions with oxygen from atmosphere occurs while the electrons travel from the lithium anode towards the cathode via an outer electrical network giving us an electrical power [59]. The discharge operation is governed by oxidation-reduction reaction. The formation of discharge product entirely depends on the nature of catalyst. During the charging operation, the discharged products are decomposed by electrochemical reaction, providing $\mathrm{Li}$ ions which travels back to the lithium anode and oxygen is released into the atmosphere. The charging of the battery is governed by oxygen evolution reaction (OER) and then electrical energy is stored as chemical energy [26].

The charging and discharging cycles in LABs can be presented using the following set of chemical reactions:

\section{Upon discharging}

$2 \mathrm{Li}+\mathrm{O}_{2} \rightarrow \mathrm{Li}_{2} \mathrm{O}_{2}$,

$4 \mathrm{Li}+\mathrm{O}_{2} \rightarrow 2 \mathrm{Li}_{2} \mathrm{O}$.

The reversible voltage for reactions given by Eq. 1 and Eq. 2 are $E^{o}=2.96 V$ and $E^{o}=2.91 V$ [60], respectively, with an open circuit voltage of around $3.7 \mathrm{~V}$ [61]. The reversible voltage can be calculated using Gibbs free energy, $E^{o}=-\Delta G / n F$ where $n$ is the representation of total number of electrons transfer in 1 molar reaction and $\mathrm{F}$ is known as Faraday's constant. Upon charging, the discharge products are decomposed giving back lithium metal at anode and oxygen back to the atmosphere.

The half-cell reactions at the anode and cathode are given by Eqs. 3, 4 and 5 .

At Anode : $\mathrm{Li} \rightarrow \mathrm{Li}^{+}+e^{-}$,

At Cathode : $2 \mathrm{Li}^{+}+\mathrm{O}_{2}+2 e^{-} \rightarrow \mathrm{Li}_{2} \mathrm{O}_{2}$,

$4 \mathrm{Li}^{+}+\mathrm{O}_{2}+4 e^{-} \rightarrow 2 \mathrm{Li}_{2} \mathrm{O}$.

In general, $\mathrm{Li}_{2} \mathrm{O}_{2}$ is the product formed during discharging of lithium air battery, the production of $\mathrm{Li}_{2} \mathrm{O}$ has low evidences. Both $\mathrm{Li}_{2} \mathrm{O}$ and $\mathrm{Li}_{2} \mathrm{O}_{2}$ are unsolvable in organic electrolyte and they get deposited in the pores of carbon cathode which ultimately results in deterioration of cyclability and capacity of cell with respect to time. Upon charging, the discharged product decomposes into lithium ions which travel back towards lithium anode and oxygen which is sent back to atmosphere. The oxygen evolution reaction (OER) is governed by Eq. 6 .

\section{Upon charging}

$\mathrm{Li}_{2} \mathrm{O}_{2} \rightarrow 2 \mathrm{Li}^{+}+2 e^{-}+\mathrm{O}_{2}$.

Different researchers have also worked on aqueous lithium air batteries [62-68]. Figure 2 describes the function of the aqueous lithium air batteries. They consist of lithium anode protected by lithium-ion conductive water stable solid electrolyte, aqueous electrolyte and carbon-based porous cathode. Water stable solid electrolyte is incorporated to protect the lithium metal from corrosion by water. In aqueous lithium air battery water molecules take part in the electrochemical reaction according to Eq. 7 and also their energy density is $30 \%$ lesser than that of aprotic one $[54,55]$. One of the major advantages of aqueous lithium air batteries is that the discharge product is easily soluble in aqueous electrolyte [69] but due to their low energy density than that of aprotic one, the major portion of the research is oriented towards aprotic lithium air batteries.

$4 \mathrm{Li}+\mathrm{O}_{2}+6 \mathrm{H}_{2} \mathrm{O} \leftrightarrow 4\left(\mathrm{LiOH} \cdot \mathrm{H}_{2} \mathrm{O}\right)$.

\section{Problems associated with operation of aprotic lithium air batteries in atmosphere}

Mostly, the research on aprotic lithium air battery was conducted using pure oxygen [69-79]. The use of pure oxygen in practical application had some serious issues like

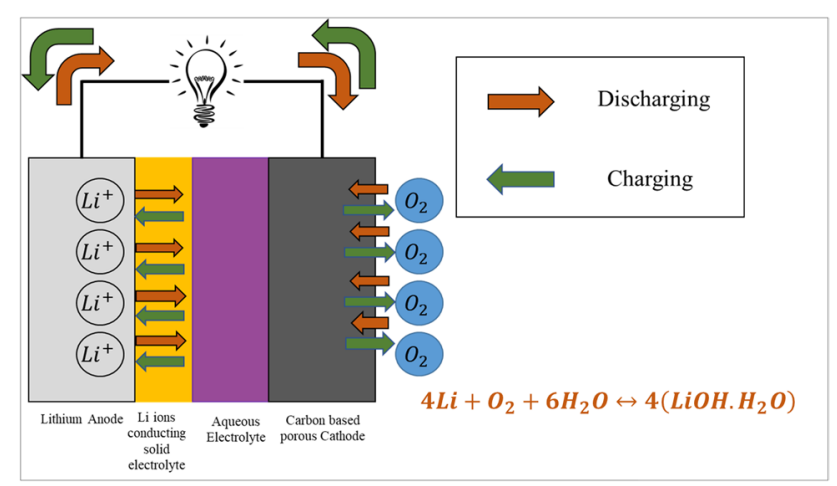

Fig. 2 Aqueous LAB working principle

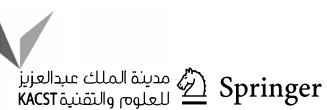


additional storage weight, refilling of cylinder and safety issues which are considered to be the hindrances in practical LAB. These hindrances can be overcome by replacing pure oxygen with air. Air is made up of nitrogen (78.1\%), oxygen $(20.9 \%)$, carbon dioxide $(0.035 \%)$ and traces of moisture [80]. It was expected that carbon dioxide and moisture content can affect the battery performance.

\section{Effects of moisture and $\mathrm{CO}_{2}$ on the battery performance}

Huang, Cui, Zhao, Sun, Guo [81] has discussed the effects of using air for oxygen supply on the performance of lithium air battery. The battery was composed of lithium anode, tetra ethylene glycol dimethyl ether (TEGDME) as electrolyte and cathode made up of carbon nanotube. It was noticed that during operation with air, the discharge product $\mathrm{Li}_{2} \mathrm{O}_{2}$ react with moisture and $\mathrm{CO}_{2}$ to form $\mathrm{LiOH}$ and $\mathrm{Li}_{2} \mathrm{CO}_{3}$, respectively. Similar formation of $\mathrm{LiOH}$ and $\mathrm{Li}_{2} \mathrm{CO}_{3}$ was also observed by Zhang and Zhou [82] and noted that the recharging is accomplished by decomposition of $\mathrm{Li}_{2} \mathrm{O}_{2}, \mathrm{LiOH}$ and $\mathrm{Li}_{2} \mathrm{CO}_{3}$ which ultimately results in high overpotential. The possible reaction upon discharging may be as followed:

$\mathrm{Li}_{2} \mathrm{O}_{2}+2 \mathrm{H}_{2} \mathrm{O}($ cold $) \rightarrow 2 \mathrm{LiOH}+\mathrm{H}_{2} \mathrm{O}_{2}$,

$2 \mathrm{Li}_{2} \mathrm{O}_{2}+2 \mathrm{H}_{2} \mathrm{O}($ hot $) \rightarrow 4 \mathrm{LiOH}+\mathrm{O}_{2}$,

$2 \mathrm{Li}_{2} \mathrm{O}_{2}+2 \mathrm{CO}_{2} \rightarrow 2 \mathrm{Li}_{2} \mathrm{CO}_{3}+\mathrm{O}_{2}$.

Upon charging, the possible decomposition of $\mathrm{LiOH}$ and $\mathrm{Li}_{2} \mathrm{CO}_{3}$ is as follows:

$2 \mathrm{LiOH} \rightarrow 2 \mathrm{Li}^{+}+2 e^{-}+1 / 2 \mathrm{O}_{2}+\mathrm{H}_{2} \mathrm{O}$,

$2 \mathrm{Li}_{2} \mathrm{CO}_{3} \rightarrow 4 \mathrm{Li}^{+}+4 e^{-}+2 \mathrm{CO}_{2}+\mathrm{O}_{2}$.

Liu, Wang, Cao, Shang, Wang, He, Yang, Cheng and Lu [83] has reviewed the side reactions in LAB due to the presence of carbon dioxide and moisture and reported that these side reactions can result in the corrosion of cathode and electrolyte degradation. The following side reactions were reported.

For $\mathrm{CO}_{2}$

$\mathrm{O}_{2}+2 \mathrm{CO}_{2}+4 \mathrm{Li} \rightarrow 2 \mathrm{Li}_{2} \mathrm{CO}_{3}$,

$\mathrm{CO}_{2}+\mathrm{Li}_{2} \mathrm{O} \rightarrow \mathrm{Li}_{2} \mathrm{CO}_{3}$,

$2 \mathrm{CO}_{2}+2 \mathrm{Li}_{2} \mathrm{O}_{2} \rightarrow 2 \mathrm{Li}_{2} \mathrm{CO}_{3}+\mathrm{O}_{2}$,
$\mathrm{CO}_{2}+2 \mathrm{LiOH} \rightarrow \mathrm{H}_{2} \mathrm{O}+\mathrm{Li}_{2} \mathrm{CO}_{3}$.

For $\mathrm{H}_{2} \mathrm{O}$

$2 \mathrm{Li}+2 \mathrm{H}_{2} \mathrm{O} \rightarrow 2 \mathrm{LiOH}+\mathrm{H}_{2}$,

$2 \mathrm{Li}_{2} \mathrm{O}_{2}+2 \mathrm{H}_{2} \mathrm{O} \rightarrow 4 \mathrm{LiOH}+\mathrm{O}_{2}$,

$4 \mathrm{Li}+\mathrm{O}_{2}+2 \mathrm{H}_{2} \mathrm{O} \rightarrow 4 \mathrm{LiOH}$.

McCloskey, Speidel, Scheffler, Miller, Viswanathan, Hummelshøj, Nørskov and Luntz [84] have discussed that discharge product $\mathrm{Li}_{2} \mathrm{O}_{2}$ can react with carbon cathode and can form $\mathrm{Li}_{2} \mathrm{CO}_{3}$ by the following reactions:

$\mathrm{Li}_{2} \mathrm{O}_{2}+\mathrm{C}+1 / 2 \mathrm{O}_{2} \rightarrow \mathrm{Li}_{2} \mathrm{CO}_{3}$,

$2 \mathrm{Li}_{2} \mathrm{O}_{2}+\mathrm{C} \rightarrow \mathrm{Li}_{2} \mathrm{O}+\mathrm{Li}_{2} \mathrm{CO}_{3}$.

The reaction of lithium with water is exothermic in nature and is governed by Eq. 17 [85]. Tan, Shyy, Zhao, Zhang and Zhu [86] has conducted experiments to find the effects of moisture on the performance of battery. They have found that the energy efficiency of the battery when operated in dry air is $66.2 \%$ and when operated in air with relative humidity of $84 \%$, the energy efficiency is $73.8 \%$. Although the energy efficiency of the battery is high when operated in moist air but moisture content can seriously deteriorate the cell life [87]. The deterioration of battery life due to corrosion of lithium anode by moisture was also found by Wang, Huang, Liu, Xie, Zhang, Zhu, Cao, Zhao [88]. The excess moisture can pass through the electrolyte and react with lithium anode and can cause the deterioration of the lithium anode governed by Eq. 17. Zhu, Liu, Rong, Chen, Yang, Jia, Yu, Karton, Ren, Xu, Adams and Wang [89] has reported that the operation of LAB with pure air is safe as long as lithium anode is protected.

Lim, Lim, Park, Seo, Gwon, Hong, Goddard and Kim [90] demonstrated that $\mathrm{Li}_{2} \mathrm{CO}_{3}$ can be disintegrated electrochemically at high voltage of $4.5 \mathrm{~V}$ which ultimately decreases the charging efficiency of lithium air battery. The decomposition of $\mathrm{Li}_{2} \mathrm{CO}_{3}$ is governed by Eq. 11. Zhang and Zhou [91] have also stated the formation of $\mathrm{Li}_{2} \mathrm{CO}_{3}$ as a discharged product when operated in pure air. Gowda and Brunet [92] have mentioned that carbon dioxide in air can react with lithium anode and can form $\mathrm{Li}_{2} \mathrm{CO}_{3}$. It was also reported that the practical rechargeable $\mathrm{LAB}$ requires the avoidance of carbon dioxide into the cell for better charging capability. The electrochemical reaction between $\mathrm{Li}$ and $\mathrm{CO}_{2}$ was governed by Eq. 22 .

$2 \mathrm{Li}+\mathrm{CO}_{2}+1 / 2 \mathrm{O}_{2} \rightarrow \mathrm{Li}_{2} \mathrm{CO}_{3}$.

Keeping in view the literature that has been discussed in this section, it can be stated that the presence of moisture is 
riskier than the presence of carbon dioxide and can significantly reduce the battery life [84]. However, for high coulombic efficiency, it is desired to avoid the carbon dioxide as well [85].

\section{Solutions to avoid moisture and $\mathrm{CO}_{2}$ contamination on lithium electrodes}

In order to operate non-aqueous lithium air battery in open air, it is required to block the moisture and carbon dioxide to go into the battery. From above discussion, it can be noted that blockage of moisture is more important than carbon dioxide to ensure the safe operation. This has been achieved by introducing a membrane known as oxygen-selective membrane (OSM) which permits only the oxygen to enter into the battery whereas blocks the moisture and carbon dioxide reach the active site [27]. The use of membrane for blocking of moisture was first suggested by Muthiah, Hsu, and Sigmund [93]. They suggested that polyvinylidene fluoride (PVDF)-Teflon amorphous fluoropolymer (AF) can be used as hydrophobic material in lithium air battery. However, they did not evaluate the electrochemical performance of the battery. Crowther and Salomon [94] were the first who came up with an idea of using Teflon coated fiberglass cloth as oxygen-selective membrane (OSM) for operation of lithium air batteries in air and reported $94 \%$ increment in the capacity. Using OSM, they have optimized quantity of $\mathrm{LiBF}_{4}$ in the electrolyte for lithium air. They have used propylene carbonate, 1,2-dimethoxyethane, dimethyl carbonate and tetra ethylene glycol dimethyl ether as an electrolyte and tested the battery in $23{ }^{\circ} \mathrm{C}$ with $23 \%$ relative humidity.

\section{Required properties of OSM}

Different researchers have studied the required properties of OSM for LAB [27, 95-101]. All of them have mentioned the following four required properties of OSM for efficient working of LAB in ambient air.

i. OSM should allow high oxygen diffusion because capacity of the battery is highly dependent on the oxygen partial pressure [102].

ii. It should be highly hydrophobic and should block the moisture to go into the battery as moisture degrades the battery capacity and cyclability.

iii. It should avoid penetration of carbon dioxide into the battery because $\mathrm{CO}_{2}$ reacts with the discharge product to form the $\mathrm{Li}_{2} \mathrm{CO}_{3}$ which ultimately decreases the battery efficiency.

iv. It should decrease the evaporation of electrolyte because during battery operation the temperature of the battery increases which ultimately results in the evaporation of electrolyte.

Crowther and Salomon [95] have also mention that two major groups can be served as potential OSMs which are perfluorocarbons and silicone-based oils.

\section{LAB operation with OSM}

Sahapatsombut, Cheng and Scott [103] modeled the LAB with silicone oil as oxygen-selective membrane with operation in air. It was demonstrated that while operating in ambient air without OSM, the capacity of the battery was much low than that of when operated in pure oxygen as shown in Fig. 3. From the model, it was demonstrated that the discharge capacity is around 4 times high as that of without using membrane as shown in Fig. 4. The model also predicts that battery can provide $800 \mathrm{mAh} / \mathrm{g}$ when discharge at a rate of $0.05 \mathrm{~mA} / \mathrm{cm}^{2}$.

Zhang, $\mathrm{Xu}$, and Liu [104] experimentally evaluated the influence of using OSM comprised of silicone oil loaded on Teflon films and porous metal sheets and reported that battery performed well in ambient air with 20-30\% relative humidity with OSM. They have also reported that the battery is able to operate for 16.3 days at a relative humidity of $20 \%$ with a capacity of $789 \mathrm{mAh} / \mathrm{g}$ and is able to provide the specific energy of $2182 \mathrm{Wh} / \mathrm{kg}$. While the reference battery which is composed of only PTFE as moisture barrier was able to run only for around 5.5 days with a specific capacity of $267 \mathrm{mAh} / \mathrm{g}$ and specific energy of $704 \mathrm{Wh} / \mathrm{kg}$. Zhang, Wang, Xu, Xiao and Williford [105] tested the battery by utilizing heat sealed polymer as OSM. The membrane not only served as the moisture resistant but also the packaging material. It was found that the battery was able to run

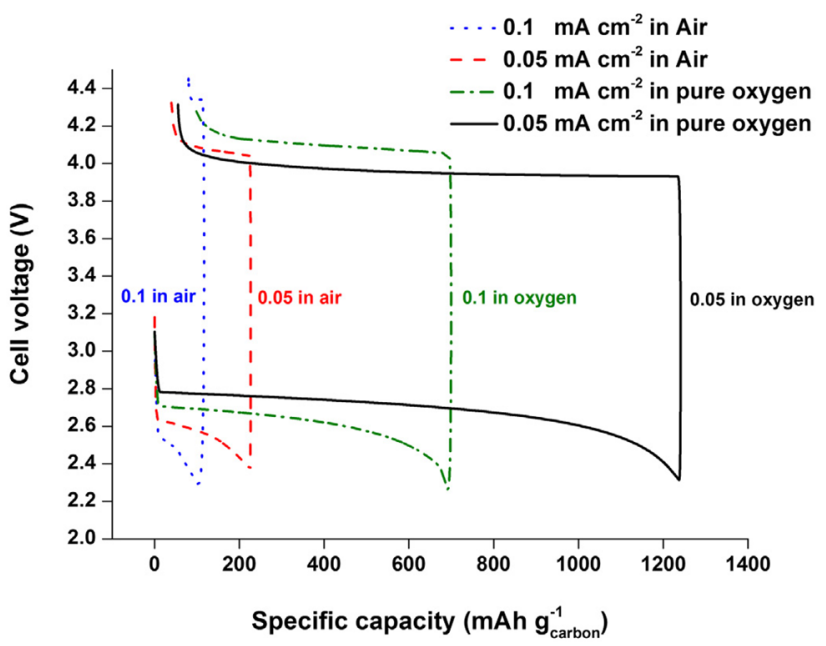

Fig. 3 Specific capacity of battery in pure oxygen and ambient air without membrane [103]

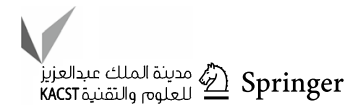




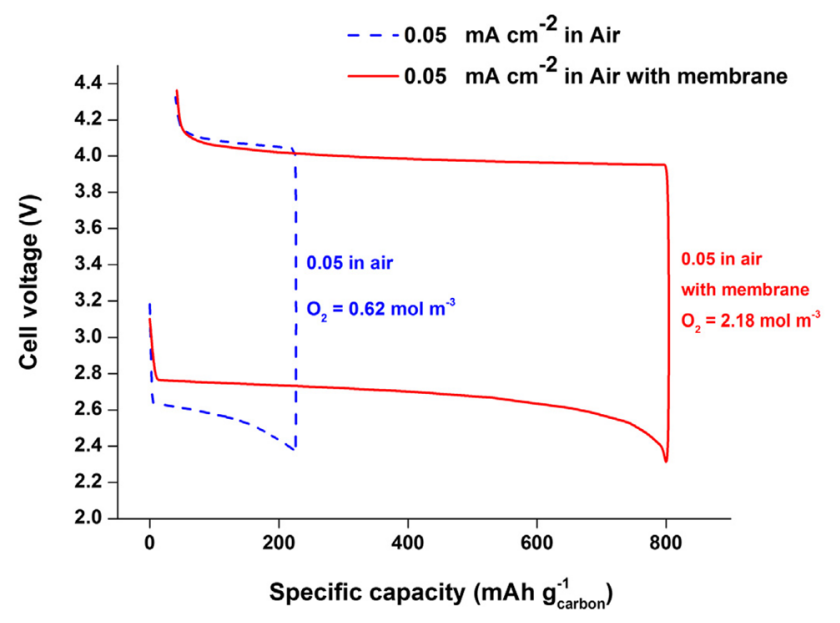

Fig. 4 Specific capacity of battery with and without OSM [103]

for a month when operated in ambient conditions and is also able to provide the capacity of $362 \mathrm{Wh} / \mathrm{kg}$. Zou, Liao, Wang, Lu, Zhou, He, Ran, Zhou, Jin and Shao [106] used silica-aerogel-based oxygen-selective membrane to check the battery cyclability in dry and humid environment. It was found that the battery with membrane in dry environment was able to run for 165 cycles when discharge at a capacity of $500 \mathrm{~mA} / \mathrm{g}$ while the battery without membrane was only able to run for 55 cycles when discharged at the same rate. While when the battery was operated in $45 \%$ relative humidity with OSM, the battery was able to run for 130 cycles at rate of $500 \mathrm{~mA} / \mathrm{g}$; however, without OSM the battery was able to operate only for 12 cycles under similar conditions as shown in Fig. 5. The discharge product when operated without membrane is $\mathrm{LiOH}$ while using membrane it was mainly $\mathrm{Li}_{2} \mathrm{O}_{2}$.

Wang, Pan, Zhang, Cheng, Liu, and Peng [107] utilized low-density polyethylene as OSM. They have reported that polyethylene is very good for the ambient operation of lithium air battery. They tested the battery in $50 \%$ relative humidity and found that battery could last till 610 cycles when discharged at a fixed capacity of $1000 \mathrm{mAh} / \mathrm{g}$. Ruan, Sun, Song, Yu, Chen, Li and Qin [108] investigated the performance of LAB using perfluorocarbon-silicone oil as oxygen-selective membrane and found that battery has a discharge capacity of $4991 \mathrm{mAh} / \mathrm{g}$. They have also found that the performance of battery with the membrane in ambient operations is comparable to the performance of battery with pure oxygen. Amici, Francia, Zeng, Bodoardo and Penazzi [109], investigated the battery using polyvinylidene fluoride co-hexafluoropropylene as OSM and tested the battery in ambient air with $17 \%$ relative humidity. It was found that battery could provide $640 \mathrm{mAh} / \mathrm{g}$ when operated with OSM which is far higher than that of without OSM. It was also found that lithium anode is also safe with the utilization of OSM. Xie, Huang, Lin, Li, Huang, Yuan, Shen, and Huang [110] have used perfluoropolyether as oxygen-selective membrane and found good hydrophobic behavior of the membrane. It was also found that battery can run up to 144 cycles and is able to provide the capacity of $500 \mathrm{mAh} / \mathrm{g}$ when discharged at $100 \mathrm{~mA} / \mathrm{g}$ while without membrane it was able to run only for 6 cycles as shown in Fig. 6 .
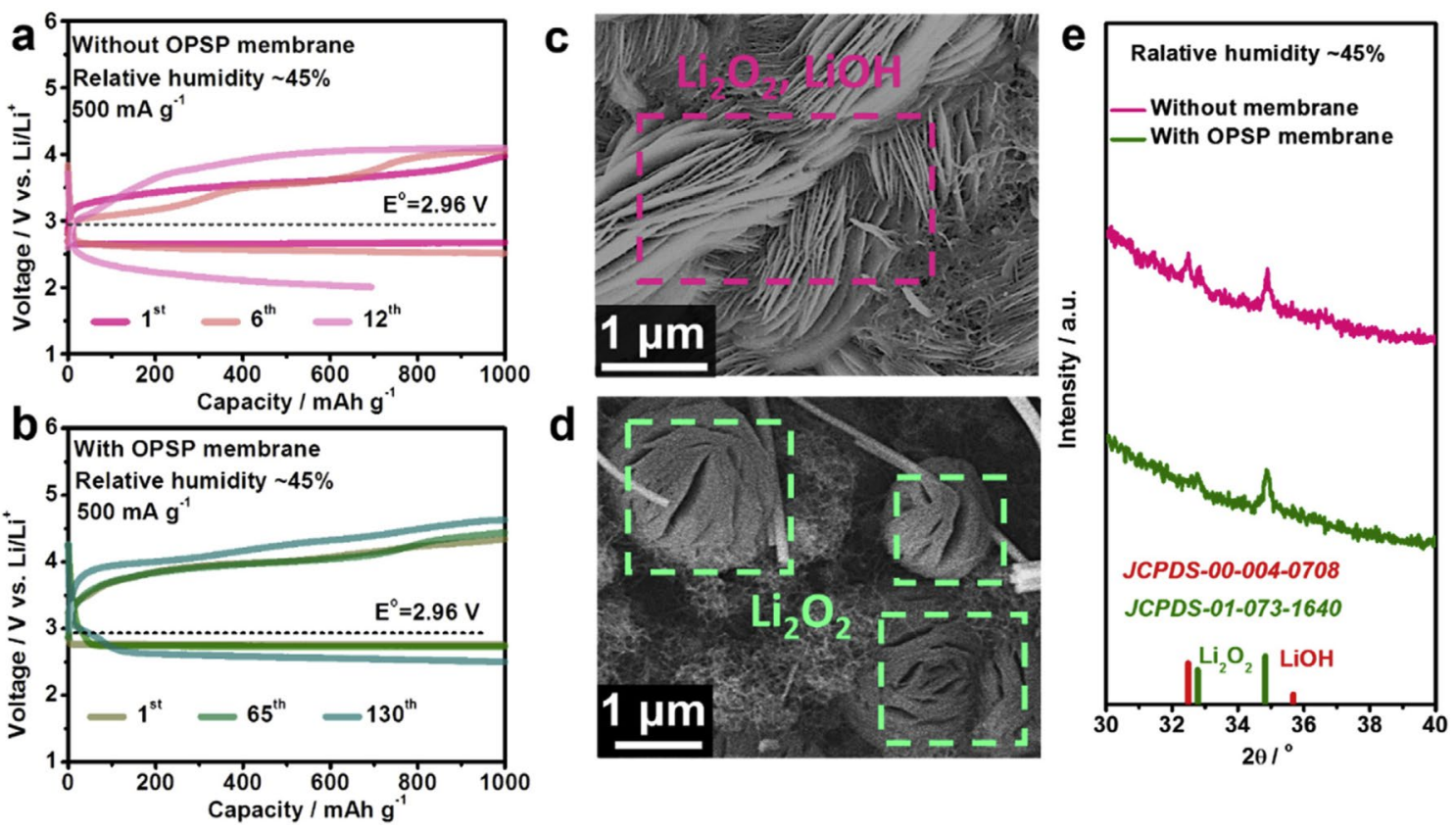

Fig. 5 Cycling comparison and discharge product of batteries without and with OPSP membrane. [106] 
Amici, Alidoost, Francia, Bodoardo, Martinez, Amantia, Biasizzo, Caldera, and Trotta [111] has added dextrin nano sponge into a poly vinylidene fluoride co-hexafluoropropylene matrix and utilized as OSM. It was found during experimentation that without OSM battery was able run just for 38 cycles at a current density of $20 \mathrm{~mA} / \mathrm{g}$ when operated in $17 \% \mathrm{RH}$ while the battery was able to run for 144 cycles with OSM when operated in same conditions. Fu, Wei, Lin, Huang and Yu [112] has tested polyaniline (PANI) membranes for blocking of moisture and found that battery could deliever $3240 \mathrm{mAh} / \mathrm{g}$ when discharge at a slower rate of $0.1 \mathrm{~mA} / \mathrm{g}$ in $20 \%$ relative humidity. Zhang, $\mathrm{Xu}, \mathrm{Li}$ and Liu [113] have used silicate zeolite and polytetrafluoroethylene for the preparation of OSM and utilized in lithium air battery. They have operated the battery for 21 days at $20 \%$ relative humidity and found that the battery is able to provide the specific capacity of $1022 \mathrm{mAh} / \mathrm{g}$ and specific energy of 2792 Wh/kg. Zhu, Zhao, Wei, Tan, and An [114] silicone oilbased OSM and reported the improved results. Lujie Cao, Fucong, Ying, Wenxi, Yifeng, Xianzhu, and Lu [115] have used mixed matrix-based membrane using polydopamine and then utilized the membrane for lithium air battery operation. They have found that the prepared membrane is very good for the blockage of moisture and carbon dioxide. The battery along with membrane is able to run for 66 cycles and is able to provide the capacity of $450 \mathrm{mAh} / \mathrm{g}$ when discharge at a fixed rate of $450 \mathrm{~mA} / \mathrm{g}$ at $30 \%$ relative humidity. Zhong, Papandrea, Xu, Lin, Zhang, Liu, Huang, and Duan [116] have utilized three-dimensional (3D) hydrophobic graphene membrane and found that operation in air with membrane is similar to that of in pure oxygen. They have reported that the battery is able to run for 100 cycles and is also able to provide the capacity of $1425 \mathrm{mAh} / \mathrm{g}$ when discharged at a rate of $2.8 \mathrm{~A} / \mathrm{g}$. Chen, Jiang, Yang, and Shen [117] has conducted the waterproofing of Carbon Black cathode with polytetrafluoroethylene and found the membrane formed over the surface of cathode which ultimately enhances the electrochemical performance of the battery. Dong, Wang, Tang, Wang, Li, Yin, and Yang [118], have used the composite membrane consist of polyethylene oxide (PEO) and polytetrafluoroethylene (PTFE) for the blockage of moisture in LAB. Several membranes by varying the proportion of PEO and PTFE were prepared. The studied proportion includes 10:30, 10:35, 10:40 and 10:50 of PEO and PTFE. It was reported that the use of such membrane is effective for moisture blocking with 10:35 is the best among all the proportions. The battery with 10:35 PEO/PTFE membrane was able to run for 230 cycles when operated in pure oxygen
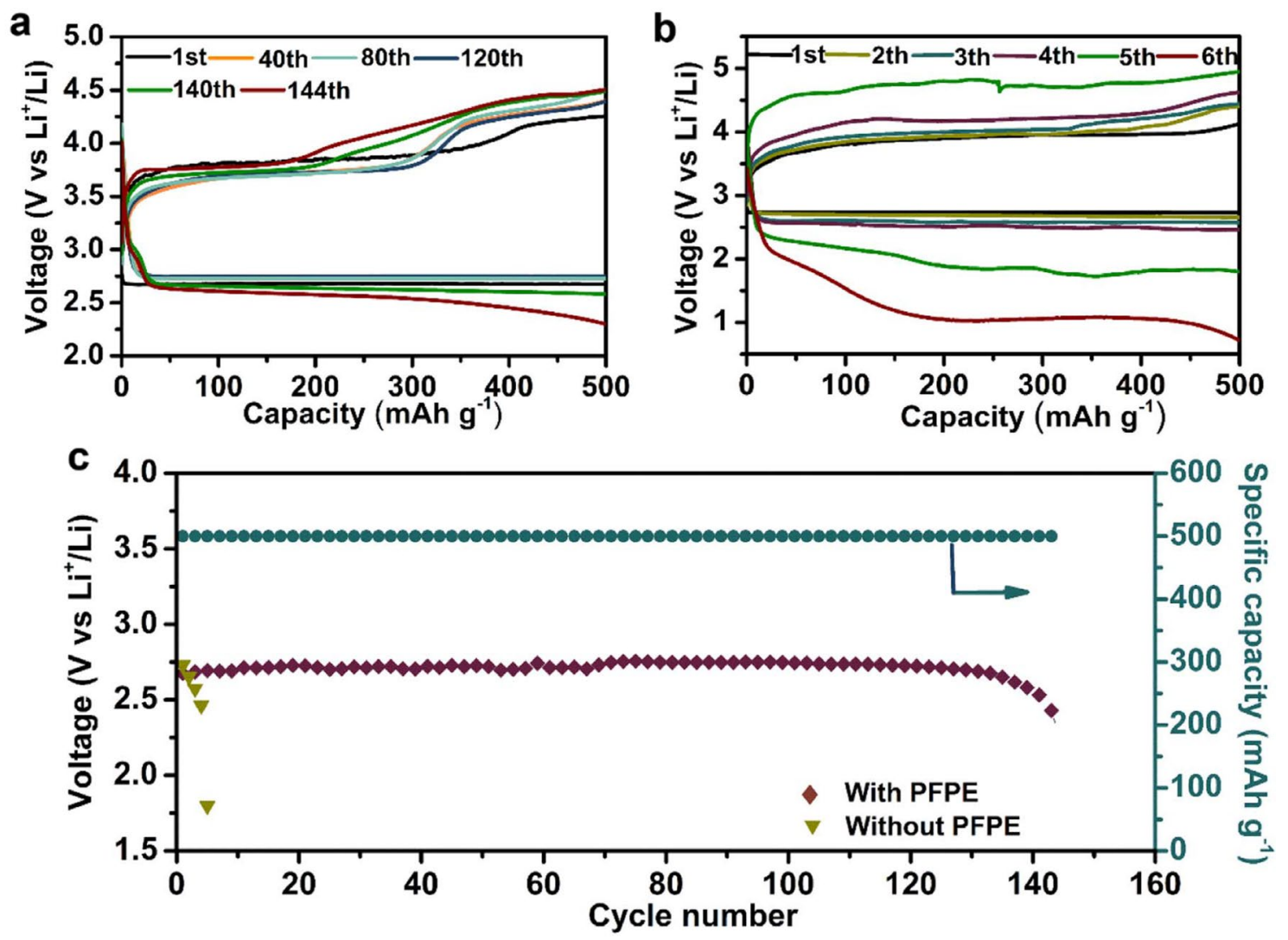

Fig. 6 Cyclic performance of LAB with and without PFPE membrane [110] 
at a fixed capacity of $1000 \mathrm{mAh} / \mathrm{gram}$ at a fixed current density of $100 \mathrm{~mA} / \mathrm{gram}$. The battery was also able to run for 55 cycles when operated in ambient air with relative humidity of $50 \%$ under the same capacity and current density. Li, Hou, Luan, Zhang, and Sun [119] have simulated the mass transfer behavior of LAB equipped with PDMS-FTBA mixed OSM. By simulation, they have found that oxygen selectivity will be maximum using PDMS and FTBA with a mass ratio of $1: 3$. The comparison of different membranes utilized by the different researchers is presented in Table 2.

The schematic of battery with OSM is shown in Fig. 7. The OSM will act as the barrier for moisture and will allow only $\mathrm{O}_{2}$ to go into the battery. $\mathrm{O}_{2}$ will react electrochemically with the lithium anode and thus providing the electrical energy. Thus, the use of OSM will improve the battery cyclability as well as capacity.

\section{Conclusion}

From the above discussion and from the literature [120-122], it can be suggested that utilization of LAB in electric vehicles is the best possible alternate of the gasoline-based transportation due to its high specific capacity. But their operation is limited due to their side reactions with moisture and carbon dioxide present in the atmosphere [123-125]. The presence of moisture in the battery is more dangerous than $\mathrm{CO}_{2}$. When $\mathrm{LAB}$ operated in air, $\mathrm{CO}_{2}$ reacts with the discharge product and forms $\mathrm{Li}_{2} \mathrm{CO}_{3}$ which decomposes at high

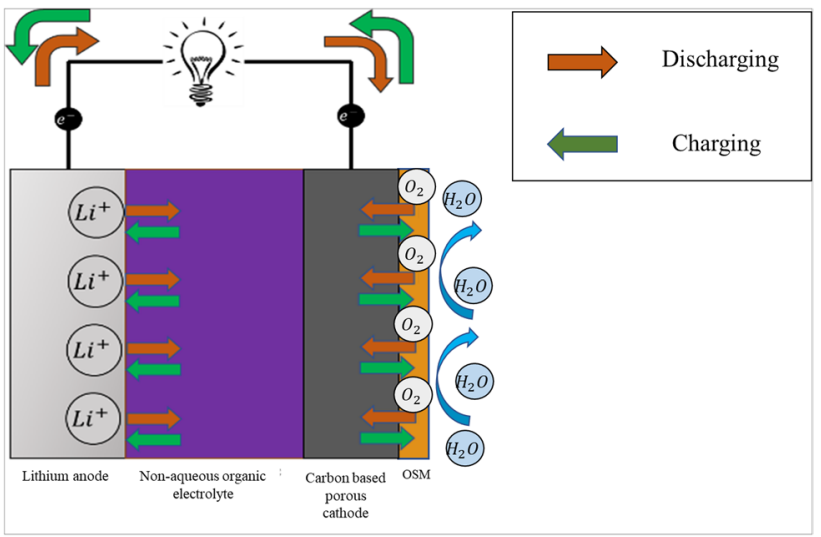

Fig. 7 Schematic of the lithium air battery with OSM

voltage and ultimately decreases the efficiency of the battery. But if moisture gets into the battery, even the traces of moisture in LAB abruptly reacts with the lithium anode and leads towards the battery failure due to exothermic reaction between $\mathrm{Li}$ anode and water. One option is the use of pure oxygen which ultimately increases the problems like additional weight of oxygen cylinder, refilling of the cylinder and some serious safety-related issues. Optimal solution for the ambient operation of lithium air battery is the use of oxygenselective membrane, which allows only oxygen to enter into the battery while blocking the moisture and carbon dioxide. Polymeric membrane including PTFE, PDMS, PFPE and polypropylene seem to be good for blockage of moisture

Table 2 Comparison of membranes utilized by different researchers to avoid moisture and carbon dioxide

\begin{tabular}{|c|c|c|c|c|c|c|c|}
\hline Membrane type & $\begin{array}{l}\text { Relative } \\
\text { humidity } \\
(\%)\end{array}$ & Current density & $\begin{array}{l}\text { Capacity with mem- } \\
\text { brane }\end{array}$ & $\begin{array}{l}\text { Capacity without } \\
\text { membrane }\end{array}$ & $\begin{array}{l}\text { No. of cycles } \\
\text { with mem- } \\
\text { brane }\end{array}$ & $\begin{array}{l}\text { No. of cycles } \\
\text { without mem- } \\
\text { brane }\end{array}$ & Reference \\
\hline Silicon oil & - & $0.05 \mathrm{~mA} / \mathrm{cm}^{2}$ & $800 \mathrm{mAh} / \mathrm{gram}$ & $210 \mathrm{mAh} / \mathrm{gram}$ & - & - & [103] \\
\hline $\begin{array}{l}\text { Silicon oil loaded on } \\
\text { PTFE }\end{array}$ & 20 & $0.05 \mathrm{~mA} / \mathrm{cm}^{2}$ & $789 \mathrm{mAh} / \mathrm{gram}$ & $267 \mathrm{mAh} /$ gram & - & - & [104] \\
\hline PDMS & 40 & $500 \mathrm{~mA} / \mathrm{gram}$ & $1000 \mathrm{mAh} / \mathrm{gram}$ & $1000 \mathrm{mAh} / \mathrm{gram}$ & 165 & 55 & [106] \\
\hline $\begin{array}{l}\text { Low-density polyeth- } \\
\text { ylene }\end{array}$ & 50 & $2000 \mathrm{~mA} / \mathrm{gram}$ & $1000 \mathrm{mAh} / \mathrm{gram}$ & $1000 \mathrm{mAh} / \mathrm{gram}$ & 610 & 100 & [107] \\
\hline $\begin{array}{l}\text { Silicon oil-loaded } \\
\text { PVDF-HFP mem- } \\
\text { brane }\end{array}$ & 17 & $0.05 \mathrm{~mA} / \mathrm{cm}^{2}$ & $650 \mathrm{mAh} / \mathrm{gram}$ & $200 \mathrm{mAh} / \mathrm{gram}$ & - & - & [108] \\
\hline PFPE & 30 & $100 \mathrm{~mA} / \mathrm{gram}$ & $500 \mathrm{mAh} / \mathrm{gram}$ & $200 \mathrm{mAh} / \mathrm{gram}$ & 144 & 6 & [109] \\
\hline $\begin{array}{l}\text { Nanosponge in } \\
\text { PVDF HFP mem- } \\
\text { brane }\end{array}$ & 17 & $20 \mathrm{~mA} / \mathrm{gram}$ & $100 \mathrm{mAh} / \mathrm{gram}$ & $100 \mathrm{mAh} / \mathrm{gram}$ & 140 & 38 & [110] \\
\hline Polyaniline & 20 & $0.2 \mathrm{~mA} / \mathrm{cm}^{2}$ & $1700 \mathrm{mAh} / \mathrm{gram}$ & $2453 \mathrm{mAh} / \mathrm{gram}$ & - & - & [111] \\
\hline $\begin{array}{l}\text { Polydopamine-coated } \\
\text { metal organic } \\
\text { framework }\end{array}$ & 30 & $200 \mathrm{~mA} / \mathrm{gram}$ & $1480 \mathrm{mAh} / \mathrm{gram}$ & $1100 \mathrm{mAh} / \mathrm{gram}$ & 66 & 7 & [112] \\
\hline $\begin{array}{l}\text { PEO and PTFE com- } \\
\text { posite membrane }\end{array}$ & 50 & $100 \mathrm{~mA} / \mathrm{gram}$ & $1000 \mathrm{mAh} / \mathrm{gram}$ & - & 55 & - & [118] \\
\hline
\end{tabular}


due to their hydrophobic nature. The batteries equipped with OSM have shown better performance than that of without membrane but showed very little cyclability and also failed to provide the high capacity and high specific energy.

\section{Future direction}

All of the above discussion shows that LAB will be the suitable candidate to replace the gasoline-based transportation, if the above-mentioned challenges have been addressed. The use of OSM can make the battery capable to operate in ambient air with high cyclability and capacity. Krichevski, Singh, Bormashenko, Multanen, and Schechter [126] have used bioinspired OSM for zinc air batteries. The membrane was made up of polycarbonate and iron (II) phthalocyanine in volatile chlorogenic solvent. The behavior of such type of membranes should be tested in LAB and their results should be tested. Such type of membrane can be used in lithium air batteries for moisture blockage. Similarly, different membranes which have been used in different metal-air batteries $[127,128]$ can be tested in LAB for blockage of moisture.

Future research should emphasize the following:

- Understanding the hydrophobic behaviors of different polymeric and inorganic membranes in lithium air batteries since there are number of hydrophobic membranes available [129-135]. However, their suitability for LABs needs to be investigated.

- Utilization of different nanoparticle in different polymeric membrane to enhance their hydrophobicity and then their utilization in lithium air batteries. The characteristics of the polymeric membranes are modified by incorporating the nanoparticles [136-142]. The use of nanoparticle-based membrane can affect the electrochemical performance of LAB.

- Optimization of electrolyte and cathode according to the type of membrane. The performance of LAB is varied with respect to the electrolyte and catalysts. Different electrolytes and catalysts should be tested with different membrane in order to select the optimized electrolyte and membrane for a particular membrane.

- Modeling of lithium air battery performance with different membrane. The membrane synthesis and testing in $\mathrm{LAB}$ is expensive and time consuming. So, it is better to develop the model for predicting the electrochemical performance of $\mathrm{LAB}$ equipped with membranes.
Funding The authors acknowledge the financial support from the Key Action 1 Erasmus+ International Credit Mobility programme KA107000598 2018-2020. This research is supported in part by a research grant from the Science Foundation Ireland (SFI) under grant number $16 / \mathrm{RC} / 3872$ and is co-funded under the European Regional Development Fund and by I-Form Industry partners.

Open Access This article is licensed under a Creative Commons Attribution 4.0 International License, which permits use, sharing, adaptation, distribution and reproduction in any medium or format, as long as you give appropriate credit to the original author(s) and the source, provide a link to the Creative Commons licence, and indicate if changes were made. The images or other third party material in this article are included in the article's Creative Commons licence, unless indicated otherwise in a credit line to the material. If material is not included in the article's Creative Commons licence and your intended use is not permitted by statutory regulation or exceeds the permitted use, you will need to obtain permission directly from the copyright holder. To view a copy of this licence, visit http://creativecommons.org/licenses/by/4.0/.

\section{References}

1. Ring, J., Lindner, M., Cross, D.F., Schlesinger, E.E.M.: Causes of the Global Warming Observed since the 19th Century. Atmos. Clim. Sci. 02, 401-415 (2012). https://doi.org/10.4236/ acs.2012.24035

2. Florides, G.A., Christodoulides, P.: Global warming and carbon dioxide through sciences. Environ. Int. 35, 390-401 (2009). https://doi.org/10.1016/j.envint.2008.07.007

3. Le Quéré, C., Barbero, L., Hauck, J., Andrew, R.M., Canadell, J.G., Sitch, S., Korsbakken, J.I.: Global carbon budget 2016 global carbon budget 2016. Earth Syst. Sci. Data. 0, 21412194 (2018)

4. Solaymani, S.: CO2 emissions patterns in 7 top carbon emitter economies: The case of transport sector. Energy 168, 9891001 (2019). https://doi.org/10.1016/j.energy.2018.11.145

5. Liu, Z., Li, L., Zhang, Y.J.: Investigating the CO2 emission differences among China's transport sectors and their influencing factors. Nat. Hazards 77, 1323-1343 (2015). https://doi.org/10. 1007/s11069-015-1657-2

6. Martin Eberhard, B., Tarpenning, M.: The 21 st Century Electric Car Tesla Motors. Tesla Motors 16, 1-10 (2006)

7. Teixeira, A.C.R., Sodré, J.R.: Impacts of replacement of engine powered vehicles by electric vehicles on energy consumption and CO2 emissions. Transp. Res. Part D: Transp. Environ. 59, 375-384 (2018). https://doi.org/10.1016/j.trd.2018.01.004

8. Gharibeh, H.F., Yazdankhah, A.S., Azizian, M.R.: Energy management of fuel cell electric vehicles based on working condition identification of energy storage systems, vehicle driving performance, and dynamic power factor. J. Energy Storage. 31, 101760 (2020). https://doi.org/10.1016/j.est.2020. 101760

9. Wilberforce, T., El-Hassan, Z., Khatib, F.N., Al Makky, A., Baroutaji, A., Carton, J.G., Olabi, A.G.: Developments of electric cars and fuel cell hydrogen electric cars. Int. J. Hydrogen Energy 42, 25695-25734 (2017). https://doi.org/10.1016/j. ijhydene.2017.07.054

10. Das, H.S., Tan, C.W., Yatim, A.H.M.: Fuel cell hybrid electric vehicles: A review on power conditioning units and topologies. Renew. Sustain. Energy Rev. 76, 268-291 (2017). https://doi. org/10.1016/j.rser.2017.03.056

11. Keipi, T., Tolvanen, H., Konttinen, J.: Economic analysis of hydrogen production by methane thermal decomposition:

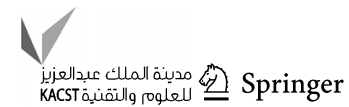


comparison to competing technologies. Energy Convers. Manage. 159, 264-273 (2018). https://doi.org/10.1016/j.enconman. 2017.12.063

12. Harper, G., Sommerville, R., Kendrick, E., Driscoll, L., Slater, P., Stolkin, R., Walton, A., Christensen, P., Heidrich, O., Lambert, S., Abbott, A., Ryder, K., Gaines, L., Anderson, P.: Recycling lithium-ion batteries from electric vehicles. Nature 575, 75-86 (2019). https://doi.org/10.1038/s41586-019-1682-5

13. Bresser, D., Hosoi, K., Howell, D., Li, H., Zeisel, H., Amine, K., Passerini, S.: Perspectives of automotive battery R\&D in China, Germany, Japan, and the USA. J. Power Sources 382, 176-178 (2018). https://doi.org/10.1016/j.jpowsour.2018.02.039

14. Eftekhari, A.: On the theoretical capacity/energy of lithium batteries and their counterparts. ACS Sustai. Chem. Eng. 7, 36843687 (2019). https://doi.org/10.1021/acssuschemeng.7b04330

15. Lee, J.S., Kim, S.T., Cao, R., Choi, N.S., Liu, M., Lee, K.T., Cho, J.: Metal-air batteries with high energy density: Li-air versus Zn-air. Adv. Energy Mater. 1, 34-50 (2011). https://doi. org/10.1002/aenm.201000010

16. Cheng, F., Chen, J.: Metal-air batteries: from oxygen reduction electrochemistry to cathode catalysts. Chem. Soc. Rev. 41, 2172-2192 (2012). https://doi.org/10.1039/c1cs15228a

17. Zhang, D., Zhao, H., Liang, F., Ma, W., Lei, Y.: Nanostructured arrays for metal-ion battery and metal-air battery applications. J. Power Sour. 493, 229722 (2021). https://doi.org/10.1016/j.jpows our.2021.229722

18. Rahman, M.A., Wang, X., Wen, C.: High energy density metalair batteries: a review. J. Electrochem. Soc. 160, A1759-A1771 (2013). https://doi.org/10.1149/2.062310jes

19. Wang, Y.J., Fang, B., Zhang, D., Li, A., Wilkinson, D.P., Ignaszak, A., Zhang, L., Zhang, J.: A Review of Carbon-Composited Materials as Air-Electrode Bifunctional Electrocatalysts for Metal-Air Batteries. Springer, Singapore (2018)

20. Han, X., Li, X., White, J., Zhong, C., Deng, Y., Hu, W., Ma, T.: Metal-air batteries: from static to flow system. Adv. Energy Mater. 8, 1-28 (2018). https://doi.org/10.1002/aenm.201801396

21. Wang, C., Yu, Y., Niu, J., Liu, Y., Bridges, D., Liu, X., Pooran, J., Zhang, Y., Hu, A.: Recent progress of metal-air batteries-a mini review. Appl. Sci. (Switzerland). 9, 1-22 (2019). https://doi. org/10.3390/app9142787

22. Goel, P., Dobhal, D., Sharma, R.C.: Aluminum-air batteries: a viability review. J. Energy Storage. (2020). https://doi.org/10. 1016/j.est.2020.101287

23. Subramanian, K., Alexander, G.V., Karthik, K., Patra, S., Indu, M.S., Sreejith, O.V., Viswanathan, R., Narayanasamy, J., Murugan, R.: A brief review of recent advances in garnet structured solid electrolyte based lithium metal batteries. J.Energy Storage. 33, 102157 (2021). https://doi.org/10.1016/j.est.2020.102157

24. Worku, A.K., Ayele, D.W., Habtu, N.G., Teshager, M.A., Workineh, Z.G.: Recent progress in $\mathrm{MnO} 2$-based oxygen electrocatalysts for rechargeable zinc-air batteries. Mater Today Sustain. 13, 100072 (2021). https://doi.org/10.1016/j.mtsust.2021.100072

25. Worku, A.K., Ayele, D.W., Habtu, N.G.: Recent advances and future perspectives in engineering of bifunctional electrocatalysts for rechargeable zinc-air batteries. Mater. Today Adv. 9, 100116 (2021). https://doi.org/10.1016/j.mtadv.2020.100116

26. Capsoni, D., Bini, M., Ferrari, S., Mustarelli, P.: Lithium-Air Batteries Based on Carbon Nanomaterials. In: Wen, L., JongBeom, B., Liming, D. (eds.) Carbon Nanomaterials for Advanced Energy Systems: Advances in Materials Synthesis and Device Applications, pp. 385-405. Wiley, Hoboken (2015)

27. Farooqui, U.R., Ahmad, A.L., Hamid, N.A.: Challenges and potential advantages of membranes in lithium air batteries: a review. Renew. Sustain. Energy Rev. 77, 1114-1129 (2017). https://doi.org/10.1016/j.rser.2016.11.220
28. Bullock, K.R.: Lead/acid batteries. J. Power Sources 51, 1-17 (1994). https://doi.org/10.1016/0378-7753(94)01952-5

29. Kwasi-Effah, C.C., Rabczuk, T.: Dimensional analysis and modelling of energy density of lithium-ion battery. J. Energy Storage. 18, 308-315 (2018). https://doi.org/10.1016/j.est.2018.05.002

30. Yadegari, H., Li, Y., Banis, M.N., Li, X., Wang, B., Sun, Q., Li, R., Sham, T.K., Cui, X., Sun, X.: On rechargeability and reaction kinetics of sodium-air batteries. Energy Environ. Sci. 7, 3747-3757 (2014). https://doi.org/10.1039/c4ee01654h

31. Zhang, T., Tao, Z., Chen, J.: Magnesium-air batteries: From principle to application. Mater. Horiz. 1, 196-206 (2014). https://doi. org/10.1039/c3mh00059a

32. Mori, R.: Recent developments for aluminum-air batteries. Electrochem. Energy Rev. 3, 344-369 (2020). https://doi.org/ 10.1007/s41918-020-00065-4

33. Xiong, C., Ren, Y.X., Jiang, H.R., Wu, M.C., Zhao, T.S.: Artificial bifunctional protective layer composed of carbon nitride nanosheets for high performance lithium-sulfur batteries. J. Energy Storage. (2019). https://doi.org/10.1016/j.est.2019. 101006

34. Mehtab, T., Yasin, G., Arif, M., Shakeel, M., Korai, R.M., Nadeem, M., Muhammad, N., Lu, X.: Metal-organic frameworks for energy storage devices: batteries and supercapacitors. J. Energy Storage. 21, 632-646 (2019). https://doi.org/10.1016/j. est.2018.12.025

35. Rahman, M.A., Wang, X., Wen, C.: A review of high energy density lithium-air battery technology. J. Appl. Electrochem. 44, 5-22 (2014). https://doi.org/10.1007/s10800-013-0620-8

36. Abraham, K.M., Jiang, Z.: Electrochemical science and technology a polymer electrolyte-based rechargeable lithium/oxygen battery. J. Electrochem. Soc. 143, 1-5 (1996)

37. Kuboki, T., Okuyama, T., Ohsaki, T., Takami, N.: Lithium-air batteries using hydrophobic room temperature ionic liquid electrolyte. J. Power Sources 146, 766-769 (2005). https://doi.org/ 10.1016/j.jpowsour.2005.03.082

38. Sandhu, S.S., Fellner, J.P., Brutchen, G.W.: Diffusion-limited model for a lithium/air battery with an organic electrolyte. J. Power Sour. 164, 365-371 (2007). https://doi.org/10.1016/j. jpowsour.2006.09.099

39. Dobley, A., Morein, C., Roark, R., Abraham, K.M.: 8.1 Large Prototype Lithium Air Batteries. In: The proceedings of the 42nd Power Sources Conference, Philadelphia, PA June 2006. 3-6 (2006)

40. Dobley, A., Dicarlo, J., Abraham, K.M.: Non-aqueous LithiumAir Batteries with an Advanced Cathode Structure. Yardley Technical Products, Inc./Lithion, Inc. Pawcatuck, CT 41st Power Sources Conference Proceedings, Philadelphia, PA,(Dec. 10, 2003). 3-6 (2004)

41. Kumar, B., Kumar, J., Leese, R., Fellner, J.P., Rodrigues, S.J., Abraham, K.M.: A solid-state, rechargeable, long cycle life lithium-air battery. J. Electrochem. Soc. 157, A50 (2010). https:// doi.org/10.1149/1.3256129

42. Sandhu, S.S., Brutchen, G.W., Fellner, J.P.: Lithium/air cell: preliminary mathematical formulation and analysis. J. Power Sources 170, 196-209 (2007). https://doi.org/10.1016/j.jpows our.2007.04.006

43. Zahoor, A., Christy, M., Jeon, J.S., Lee, Y.S., Nahm, K.S.: Improved lithium oxygen battery performance by addition of palladium nanoparticles on manganese oxide nanorod catalysts. J. Solid State Electrochem. 19, 1501-1509 (2015). https://doi. org/10.1007/s10008-015-2739-5

44. Zahoor, A., Jang, H.S., Jeong, J.S., Christy, M., Hwang, Y.J., Nahm, K.S.: A comparative study of nanostructured $\alpha$ and $\delta \mathrm{MnO} 2$ for lithium oxygen battery application. RSC Adv. 4, 8973-8977 (2014). https://doi.org/10.1039/c3ra47659f 
45. Zahoor, A., Christy, M., Hwang, Y.-J., Nahm, K.-S.: Lithium Air Battery: Alternate Energy Resource for the Future. J. Electrochem. Sci. Technol. 3, 14-23 (2012). https://doi.org/10.5229/ jecst.2012.3.1.14

46. Geng, D., Ding, N., Hor, T.S.A., Chien, S.W., Liu, Z., Wuu, D., Sun, X., Zong, Y.: From lithium-oxygen to lithium-air batteries: challenges and opportunities. Adv. Energy Mater. 6, 1-14 (2016). https://doi.org/10.1002/aenm.201502164

47. Sarkar, J., Bhattacharyya, S.: Application of graphene and graphene-based materials in clean energy-related devices Minghui. Archives of Thermodynamics. 33, 23-40 (2012)

48. Sahapatsombut, U., Cheng, H., Scott, K.: Modelling of electrolyte degradation and cycling behaviour in a lithium-air battery. J. Power Sources 243, 409-418 (2013). https://doi.org/10.1016/j. jpowsour.2013.06.043

49. Temprano, I., Liu, T., Petrucco, E., Ellison, J.H.J., Kim, G., Jónsson, E., Grey, C.P.: Toward reversible and moisture-tolerant aprotic lithium-air batteries. Joule. 4, 2501-2520 (2020). https:// doi.org/10.1016/j.joule.2020.09.021

50. Asadi, M., Sayahpour, B., Abbasi, P., Ngo, A.T., Karis, K., Jokisaari, J.R., Liu, C., Narayanan, B., Gerard, M., Yasaei, P., Hu, X., Mukherjee, A., Lau, K.C., Assary, R.S., Khalili-Araghi, F., Klie, R.F., Curtiss, L.A., Salehi-Khojin, A.: A lithium-oxygen battery with a long cycle life in an air-like atmosphere. Nature 555, 502-506 (2018). https://doi.org/10.1038/nature25984

51. Grande, L., Paillard, E., Hassoun, J., Park, J.B., Lee, Y.J., Sun, Y.K., Passerini, S., Scrosati, B.: The lithium/air battery: Still an emerging system or a practical reality? Adv. Mater. 27, 784-800 (2015). https://doi.org/10.1002/adma.201403064

52. He, P., Zhang, T., Jiang, J., Zhou, H.: Lithium-Air Batteries with Hybrid Electrolytes. J. Phys. Chem. Lett. 7, 1267-1280 (2016). https://doi.org/10.1021/acs.jpclett.6b00080

53. Li, O.L., Ishizaki, T.: Development, challenges, and prospects of carbon-based electrode for lithium-air batteries. Elsevier Inc. (2018)

54. Imanishi, N., Yamamoto, O.: Perspectives and challenges of rechargeable lithium-air batteries. Mater. Today Adv. 4, 100031 (2019). https://doi.org/10.1016/j.mtadv.2019.100031

55. Sunahiro, S., Matsui, M., Takeda, Y., Yamamoto, O., Imanishi, N.: Rechargeable aqueous lithium-air batteries with an auxiliary electrode for the oxygen evolution. J. Power Sour. 262, 338-343 (2014). https://doi.org/10.1016/j.jpowsour.2014.03.016

56. Safanama, D., Damiano, D., Rao, R.P., Adams, S.: Lithium conducting solid electrolyte Li1 + xAl xGe2 - X(PO4)3 membrane for aqueous lithium air battery. Solid State Ionics 262, 211-215 (2014). https://doi.org/10.1016/j.ssi.2013.11.031

57. Song, S., Qin, X., Ruan, Y., Li, W., Xu, Y., Zhang, D., Thokchom, J.: Enhanced performance of solid-state lithium-air batteries with continuous 3D garnet network added composite polymer electrolyte. J. Power Sour. 461, 228146 (2020). https://doi.org/10. 1016/j.jpowsour.2020.228146

58. Das, S.K., Sarkar, A.: Synthesis and performance evaluation of a solid electrolyte and air cathode for a rechargeable lithiumair battery. In: ASME 2016 14th International Conference on Fuel Cell Science, Engineering and Technology, FUELCELL 2016, collocated with the ASME 2016 Power Conference and the ASME 2016 10th International Conference on Energy Sustainability. 74-89 (2016). https://doi.org/10.1115/FUELCELL20 16-59448

59. Ogasawara, T., Débart, A., Holzapfel, M., Novák, P., Bruce, P.G.: Rechargeable Li2O2 electrode for lithium batteries. J. Am. Chem. Soc. 128, 1390-1393 (2006). https://doi.org/10.1021/ ja056811q

60. NIST-JANAF Thermochemical Tables Lithium. J. Phys. Chem. Ref. Data 1493-1527 (1988)
61. Zhang, T., Imanishi, N., Hasegawa, S., Hirano, A., Xie, J., Takeda, Y., Yamamoto, O., Sammes, N.: Li/Polymer electrolyte/water stable lithium-conducting glass ceramics composite for lithium-air secondary batteries with an aqueous electrolyte. J. Electrochem. Soc. 155, A965 (2008). https://doi. org/10.1149/1.2990717

62. Zhang, T., Imanishi, N., Hasegawa, S., Hirano, A., Xie, J., Takeda, Y., Yamamoto, O., Sammes, N.: Water-stable lithium anode with the three-layer construction for aqueous lithium-air secondary batteries. Electrochem. Solid-State Lett. 12, 132-135 (2009). https://doi.org/10.1149/1.3125285

63. Puech, L., Cantau, C., Vinatier, P., Toussaint, G., Stevens, P.: Elaboration and characterization of a free standing LiSICON membrane for aqueous lithium-air battery. J. Power Sour. 214, 330-336 (2012). https://doi.org/10.1016/j.jpowsour.2012.04.064

64. Zhao, C., Shu, C., Zheng, R., Du, D., Ren, L., He, M., Li, R., Xu, H., Wen, X., \& Long, J.: Adjusting the d-bandcenter of metallic sites in NiFe-based Bimetal-organic frameworks via tensile strain to achieve High-performanceoxygen electrode catalysts for Lithium-oxygen batteries. J. Colloid Interface Sci. 607, 12151225(2022). https://doi.org/10.1016/j.jcis.2021.09.077

65. Manthiram, A., Li, L.: Hybrid and aqueous lithium-air batteries. Adv. Energy Mater. 5, 1-17 (2015). https://doi.org/10.1002/ aenm.201401302

66. Ahmed, M., Mitha, A., Chen, P.: Scalable porous zinc anode to improve the cycling performance of aqueous lithium energy storage systems. J. Energy Storage. 21, 481-488 (2019). https:// doi.org/10.1016/j.est.2018.12.014

67. Lu, S.H., Lu, H.C.: Pouch-type hybrid Li-air battery enabled by flexible composite lithium-ion conducting membrane. J. Power Sour. 489, 229431 (2021). https://doi.org/10.1016/j.jpowsour. 2020.229431

68. Takagi, H., Kakimoto, K., Mori, D., Taminato, S., Takeda, Y., Yamamoto, O., Imanishi, N.: High energy density rechargeable aqueous lithium batteries with an aqueous hydroquinone sulfonic acid and benzoquinone sulfonic acid redox couple cathode. J. Energy Power Technol. 3, 1-13 (2021)

69. Li, Y., Wang, J., Li, X., Geng, D., Li, R., Sun, X.: Superior energy capacity of graphene nanosheets for a nonaqueous lithium-oxygen battery. Chem. Commun. 47, 9438-9440 (2011). https://doi.org/10.1039/c1cc13464g

70. Mirzaeian, M., Hall, P.J.: Characterizing capacity loss of lithium oxygen batteries by impedance spectroscopy. J. Power Sour. 195, 6817-6824 (2010). https://doi.org/10.1016/j.jpowsour.2010.04. 064

71. Kwak, W.J., Lim, H.S., Gao, P., Feng, R., Chae, S., Zhong, L., Read, J., Engelhard, M.H., Xu, W., Zhang, J.G.: Effects of fluorinated diluents in localized high-concentration electrolytes for lithium-oxygen batteries. Adv. Func. Mater. 31, 1-7 (2021). https://doi.org/10.1002/adfm.202002927

72. Li, J.H., Wu, J., Yu, Y.X.: Theoretical exploration of single-layer $\mathrm{T} 12 \mathrm{O}$ as a catalyst in lithium-oxygen battery cathodes. J. Phys. Chem. C 124, 9089-9098 (2020). https://doi.org/10.1021/acs. jpcc.9b09665

73. Elia, G.A., Park, J.B., Sun, Y.K., Scrosati, B., Hassoun, J.: Role of the lithium salt in the performance of lithium- oxygen batteries: a comparative study. ChemElectroChem 1, 47-50 (2014). https://doi.org/10.1002/celc.201300160

74. Sun, D., Shen, Y., Zhang, W., Yu, L., Yi, Z., Yin, W., Wang, D., Huang, Y., Wang, J., Wang, D., Goodenough, J.B.: A solutionphase bifunctional catalyst for lithium-oxygen batteries. J. Am. Chem. Soc. 136, 8941-8946 (2014). https://doi.org/10.1021/ ja501877e

75. Li, X., Liu, J., Zhang, J., Wu, S., Zhang, D., Shui, J.: Interface engineering of $\mathrm{NiCo} 2 \mathrm{O} 4 / \mathrm{BCN}$ nanotube for performance

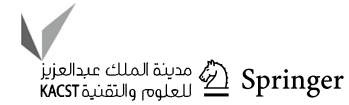


enhancement of lithium-oxygen battery. Chem. Eng. J. 411, 128403 (2021). https://doi.org/10.1016/j.cej.2021.128403

76. Kang, J.: An ultrahigh power Li-O2 battery. Mater. Today Commun. 27, 102412 (2021). https://doi.org/10.1016/j.mtcomm. 2021.102412

77. Luo, Z., Li, F., Hu, C., Li, D., Cao, Y., Scott, K., Gong, X., Luo, K.: Impact of a gold nanocolloid electrolyte on $\mathrm{Li} 2 \mathrm{O} 2$ morphology and performance of a lithium-oxygen battery. ACS Appl. Mater. Interfaces. 13, 4062-4071 (2021). https://doi.org/10.1021/ acsami.0c20871

78. Zhou, Y., Yan, D., Gu, Q., Zhu, S., Wang, L., Peng, H., Zhao, Y.: Implanting cation vacancies in $\mathrm{Ni}-\mathrm{Fe} \mathrm{LDHs}$ for efficient oxygen evolution reactions of lithium-oxygen batteries. Appl. Catal. B 285, 119792 (2021). https://doi.org/10.1016/j.apcatb. 2020.119792

79. Zhang, Y., Jiang, F., Jiang, H., Yamamoto, O., Zhang, T.: Dispersion hydrophobic electrolyte enables lithium-oxygen battery enduring saturated water vapor. J. Energy Chem. 64, 511-519 (2022). https://doi.org/10.1016/j.jechem.2021.05.013

80. Masters, G.M.: Renewable and efficient electric power systems, p. 676. Wiley, Canada (2004)

81. Huang, S., Cui, Z., Zhao, N., Sun, J., Guo, X.: Influence of ambient air on cell reactions of li-air batteries. Electrochim. Acta 191, 473-478 (2016). https://doi.org/10.1016/j.electacta.2016.01.102

82. Zhang, T., Zhou, H.: A reversible long-life lithium-air battery in ambient air. Nat. Commun. 4, 1817 (2013). https://doi.org/10. 1038/ncomms 2855

83. Liu, Y., Wang, L., Cao, L., Shang, C., Wang, Z., Wang, H., He, L., Yang, J., Cheng, H., Li, J., Lu, Z.: Understanding and suppressing side reactions in $\mathrm{Li}$-air batteries. Mater. Chem. Front. 1, 2495-2510 (2017). https://doi.org/10.1039/c7qm00353f

84. McCloskey, B.D., Speidel, A., Scheffler, R., Miller, D.C., Viswanathan, V., Hummelshøj, J.S., Nørskov, J.K., Luntz, A.C.: Twin problems of interfacial carbonate formation in nonaqueous $\mathrm{Li}-\mathrm{O}$ 2 batteries. J. Phys. Chem. Lett. 3, 997-1001 (2012). https://doi. org/10.1021/jz300243r

85. Klanchar, M., Wintrode, B.D., Phillips, J.A.: Lithium-water reaction chemistry at elevated temperature. Energy Fuels 11, 931-935 (1997). https://doi.org/10.1021/ef970047e

86. Tan, P., Shyy, W., Zhao, T.S., Zhang, R.H., Zhu, X.B.: Effects of moist air on the cycling performance of non-aqueous lithium-air batteries. Appl. Energy 182, 569-575 (2016). https://doi.org/10. 1016/j.apenergy.2016.08.113

87. Cho, M.H., Trottier, J., Gagnon, C., Hovington, P., Clément, D., Vijh, A., Kim, C.S., Guerfi, A., Black, R., Nazar, L., Zaghib, $\mathrm{K}$.: The effects of moisture contamination in the Li-O2 battery. J. Power Sour. 268, 565-574 (2014). https://doi.org/10.1016/j. jpowsour.2014.05.148

88. Wang, G., Huang, L., Liu, S., Xie, J., Zhang, S., Zhu, P., Cao, G., Zhao, X.: Understanding moisture and carbon dioxide involved interfacial reactions on electrochemical performance of lithiumair batteries catalyzed by gold/manganese-dioxide. ACS Appl. Mater. Interfaces. 7, 23876-23884 (2015). https://doi.org/10. 1021/acsami.5b05250

89. Zhu, Y.G., Liu, Q., Rong, Y., Chen, H., Yang, J., Jia, C., Yu, L.J., Karton, A., Ren, Y., Xu, X., Adams, S., Wang, Q.: Proton enhanced dynamic battery chemistry for aprotic lithium-oxygen batteries. Nat. Commun. 8, 4-11 (2017). https://doi.org/10.1038/ ncomms 14308

90. Lim, H.K., Lim, H.D., Park, K.Y., Seo, D.H., Gwon, H., Hong, J., Goddard, W.A., Kim, H., Kang, K.: Toward a lithium-“Air" battery: the effect of $\mathrm{CO} 2$ on the chemistry of a lithium-oxygen cell. J. Am. Chem. Soc. 135, 9733-9742 (2013). https://doi.org/ 10.1021/ja4016765

91. Zhang, T., Zhou, H.: From Li-O 2 to Li-Air batteries: carbon nanotubes/ionic liquid gels with a tricontinuous passage of electrons, ions, and oxygen. Angew. Chem. 51, 11062-11067 (2012). https://doi.org/10.1002/anie.201204983

92. Gowda, S.R., Brunet, A., Mccloskey, B.D.: Implications of CO 2 Contamination in Rechargeable Nonaqueous Li-. J. Phys. Chem. Lett. 4(2), 276-279 (2013). https://doi.org/10.1021/jz301902h

93. Muthiah, P., Hsu, S.H., Sigmund, W.: Coaxially electrospun PVDF-teflon AF and teflon AF-PVDF core-sheath nanofiber mats with superhydrophobic properties. Langmuir 26, 12483 12487 (2010). https://doi.org/10.1021/la100748g

94. Crowther, O., Keeny, D., Moureau, D. M., Meyer, B., Salomon, M., \& Hendrickson, M.: Electrolyte optimization forthe primary lithium metal air battery using an oxygen selective membrane. J. Power Sources. 202, 347-351(2012). https://doi.org/10.1016/j. jpowsour.2011.11.024

95. Crowther, O., Salomon, M.: Oxygen selective membranes for Li-air (O2) batteries. Membranes 2, 216-227 (2012). https://doi. org/10.3390/membranes2020216

96. Zhang, C., Sunarso, J., Liu, S.: Designing CO2-resistant oxygenselective mixed ionic-electronic conducting membranes: guidelines, recent advances, and forward directions. Chem. Soc. Rev. 46, 2941-3005 (2017). https://doi.org/10.1039/c6cs00841k

97. Liu, L., Guo, H., Fu, L., Chou, S., Thiele, S., Wu, Y., Wang, J.: Critical advances in ambient air operation of nonaqueous rechargeable li-air batteries. Small 17, 1-32 (2021). https://doi. org/10.1002/smll.201903854

98. Zeng, P., Ran, R., Chen, Z., Gu, H., Shao, Z., da Costa, J.C.D., Liu, S.: Significant effects of sintering temperature on the performance of $\mathrm{La} 0.6 \mathrm{Sr} 0.4 \mathrm{Co} 0.2 \mathrm{Fe} 0.8 \mathrm{O} 3-\delta$ oxygen selective membranes. J. Membr. Sci. 302, 171-179 (2007)

99. Ge, L., Ran, R., Zhang, K., Liu, S., Shao, Z.: Oxygen selective membranes based on B-site cation-deficient (Ba0.5Sr0.5) $(\mathrm{Co} 0.8 \mathrm{Fe} 0.2) \mathrm{yO} 3-\delta$ perovskite with improved operational stability. J. Membr. Sci. 318, 182-190 (2008). https://doi.org/10. 1016/j.memsci.2008.02.015

100. Kang, J.H., Lee, J., Jung, J.W., Park, J., Jang, T., Kim, H.S., Nam, J.S., Lim, H., Yoon, K.R., Ryu, W.H., Kim, I.D., Byon, H.R.: Lithium-air batteries: air-breathing challenges and perspective. ACS Nano 14, 14549-14578 (2020). https://doi.org/ 10.1021/acsnano.0c07907

101. Tan, P., Jiang, H.R., Zhu, X.B., An, L., Jung, C.Y., Wu, M.C., Shi, L., Shyy, W., Zhao, T.S.: Advances and challenges in lithium-air batteries. Appl. Energy 204, 780-806 (2017). https:// doi.org/10.1016/j.apenergy.2017.07.054

102. Kwon, H.J., Lee, H.C., Ko, J., Jung, I.S., Lee, H.C., Lee, H., Kim, M., Lee, D.J., Kim, H., Kim, T.Y., Im, D.: Effects of oxygen partial pressure on Li-air battery performance. J. Power Sour. 364, 280-287 (2017). https://doi.org/10.1016/j.jpowsour. 2017.08.052

103. Sahapatsombut, U., Cheng, H., Scott, K.: Modelling of operation of a lithium-air battery with ambient air and oxygen-selective membrane. J. Power Sour. 249, 418-430 (2014). https:// doi.org/10.1016/j.jpowsour.2013.10.128

104. Zhang, J., Xu, W., Liu, W.: Oxygen-selective immobilized liquid membranes for operation of lithium-air batteries in ambient air. J. Power Sour. 195, 7438-7444 (2010). https://doi.org/10.1016/j. jpowsour.2010.05.028

105. Zhang, J.G., Wang, D., Xu, W., Xiao, J., Williford, R.E.: Ambient operation of Li/Air batteries. J. Power Sour. 195, 4332-4337 (2010). https://doi.org/10.1016/j.jpowsour.2010.01.022

106. Zou, X., Liao, K., Wang, D., Lu, Q., Zhou, C., He, P., Ran, R., Zhou, W., Jin, W., Shao, Z.: Water-proof, electrolyte-nonvolatile, and flexible Li-Air batteries via O2-Permeable silica-aerogelreinforced polydimethylsiloxane external membranes. Energy Storage Mater. 27, 297-306 (2020). https://doi.org/10.1016/j. ensm.2020.02.014 
107. Wang, L., Pan, J., Zhang, Y., Cheng, X., Liu, L., Peng, H.: A Li-air battery with ultralong cycle life in ambient air. Adv. Mater. 30, 1-6 (2018). https://doi.org/10.1002/adma.201704378

108. Ruan, Y., Sun, J., Song, S., Yu, L., Chen, B., Li, W., Qin, X.: A perfluorocarbon-silicone oil oxygen-selective membrane for ambient operation of aprotic $\mathrm{Li}$-air batteries. Electrochem. Commun. 96, 93-97 (2018). https://doi.org/10.1016/j.elecom.2018. 10.013

109. Amici, J., Francia, C., Zeng, J., Bodoardo, S., Penazzi, N.: Protective PVDF-HFP-based membranes for air de-hydration at the cathode of the rechargeable Li-air cell. J. Appl. Electrochem. 46, 617-626 (2016). https://doi.org/10.1007/s10800-016-0951-3

110. Xie, M., Huang, Z., Lin, X., Li, Y., Huang, Z., Yuan, L., Shen, Y., Huang, Y.: Oxygen selective membrane based on perfluoropolyether for Li-Air battery with long cycle life. Energy Storage Mater. 20, 307-314 (2019). https://doi.org/10.1016/j.ensm.2018. 11.023

111. Amici, J., Alidoost, M., Francia, C., Bodoardo, S., Martinez Crespiera, S., Amantia, D., Biasizzo, M., Caldera, F., Trotta, F.: $\mathrm{O} 2$ selective membranes based on a dextrin-nanosponge (NS) in a PVDF-HFP polymer matrix for Li-air cells. Chem. Commun. 52, 13683-13686 (2016). https://doi.org/10.1039/c6cc06954a

112. Fu, Z., Wei, Z., Lin, X., Huang, T., Yu, A.: Polyaniline membranes as waterproof barriers for lithium air batteries. Electrochim. Acta 78, 195-199 (2012). https://doi.org/10.1016/j.elect acta.2012.05.153

113. Zhang, J., Xu, W., Li, X., Liu, W.: Air dehydration membranes for nonaqueous lithium-air batteries. J. Electrochem. Soc. 157, A940 (2010). https://doi.org/10.1149/1.3430093

114. Zhu, X.B., Zhao, T.S., Wei, Z.H., Tan, P., An, L.: A high-rate and long cycle life solid-state lithium-air battery. Energy Environ. Sci. 8, 3745-3754 (2015). https://doi.org/10.1039/c5ee02867a

115. Cao, L., Lv, F., Liu, Y., Wang, W., Huo, Y., Sun, X.F., Lu, A.Z. A high performance $\mathrm{O} 2$ selective membrane based on CAU-1NH2@polydopamine and PMMA polymer for Li-Air Batteries. Angew. Chem. 6(11), 951-952 (1967)

116. Zhong, X., Papandrea, B., Xu, Y., Lin, Z., Zhang, H., Liu, Y., Huang, Y., Duan, X.: Three-dimensional graphene membrane cathode for high energy density rechargeable lithium-air batteries in ambient conditions. Nano Res. 10, 472-482 (2017). https:// doi.org/10.1007/s12274-016-1306-4

117. Chen, M., Jiang, X., Yang, H., Shen, P.K.: Performance improvement of air electrode for Li/air batteries by hydrophobicity adjustment. J. Mater. Chem. A. 3, 11874-11879 (2015). https:// doi.org/10.1039/c5ta01601k

118. Dong, H., Wang, Y., Tang, P., Wang, H., Li, K., Yin, Y., Yang, S.: A novel strategy for improving performance of lithium-oxygen batteries. J. Coll. Interface Sci. 584, 246-252 (2021). https://doi. org/10.1016/j.jcis.2020.09.096

119. Li, J., Hou, L., Luan, L., Zhang, T., Sun, H.: Study of mass transfer behaviour in a PDMS-FTBA mixed oxygen selective membrane for Li-air batteries. Int. J. Electrochem. Sci. 16, 1-16 (2021)

120. Zahoor, A., Ghouri, Z.K., Hashmi, S., Raza, F., Ishtiaque, S., Nadeem, S., Ullah, I., Nahm, K.S.: Electrocatalysts for lithiumair batteries: current status and challenges. ACS Sustain. Chem. Eng. 7, 14288-14320 (2019). https://doi.org/10.1021/acssuschem eng. 8 b06351

121. Imanishi, N., Yamamoto, O.: Rechargeable lithium-air batteries: characteristics and prospects. Mater. Today 17, 24-30 (2014). https://doi.org/10.1016/j.mattod.2013.12.004

122. Bi, X., Amine, K., Lu, J.: The importance of anode protection towards lithium oxygen batteries. J. Mater. Chem. A. 8, 35633573 (2020). https://doi.org/10.1039/c9ta12414d

123. Liu, T., Feng, X., Jin, X., Shao, M., Su, Y., Zhang, Y., Zhang, X.: Protecting the lithium metal anode for a safe flexible lithium-air battery in ambient air. Angew. Chem. 131, 18408-18413 (2019). https://doi.org/10.1002/ange.201911229

124. Bao, J., Li, C., Zhang, F., Wang, P., Zhang, X., He, P., Zhou, H.: A liquid anode of lithium biphenyl for highly safe lithium-air battery with hybrid electrolyte. Batter. Supercaps 3, 708-712 (2020). https://doi.org/10.1002/batt.202000092

125. Chen, K., Yang, D.-Y., Huang, G., X-B, Z.: Lithium-air batteries: air-electrochemistry and anode stabilization. Acc. Chem. Res. 54, 632-641 (2021)

126. Krichevski, O., Singh, R.K., Bormashenko, E., Bormashenko, Y., Multanen, V., Schechter, A.: Bioinspired oxygen selective membrane for Zn-air batteries. J. Mater. Sci. 56, 9382-9394 (2021). https://doi.org/10.1007/s10853-021-05880-8

127. Khan, Z., Parveen, N., Ansari, S.A., Senthilkumar, S.T., Park, S., Kim, Y., Cho, M.H., Ko, H.: Three-dimensional SnS2 nanopetals for hybrid sodium-air batteries. Electrochim. Acta 257, 328-334 (2017). https://doi.org/10.1016/j.electacta.2017.10.063

128. Tsehaye, M.T., Alloin, F., Iojoiu, C., Tufa, R.A., Aili, D., Fischer, P., Velizarov, S.: Membranes for zinc-air batteries: recent progress, challenges and perspectives. J. Power Sour. 475, 228689 (2020). https://doi.org/10.1016/j.jpowsour.2020.228689

129. Uniyal, D., Prasad, B., Nithin Kumar, K.C., Chandra, S., Panwar, V., Juneja, P., Agarwal, V., Gill, F.S.: Impedance characteristics analysis of $\mathrm{rGO}$ /polymers (PVDF, PMMA, PTFE) nanocomposite membranes. Mater. Today Proc. 26, 320-323 (2019). https:// doi.org/10.1016/j.matpr.2019.11.309

130. Khan, U., Biccai, S., Boland, C.S., Coleman, J.N.: Low cost, high performance ultrafiltration membranes from glass fiber-PTFEgraphene composites. Sci. Rep. 10, 1-11 (2020). https://doi.org/ 10.1038/s41598-020-78091-x

131. Yu, S., Zhu, Z., Zhou, M., Yu, H., Kang, G., Cao, Y.: Fabrication and characterization of a novel Nafion-PTFE composite hollow fiber membrane. J. Appl. Polym. Sci. 138, 1-13 (2021). https:// doi.org/10.1002/app.50254

132. Hou, X., Deem, P.T., Choy, K.L.: Hydrophobicity study of polytetrafluoroethylene nanocomposite films. Thin Solid Films 520, 4916-4920 (2012). https://doi.org/10.1016/j.tsf.2012.02.074

133. Ren, J., Li, J., Xu, Z., Liu, Y., Cheng, F.: Simultaneous antifouling and flux-enhanced membrane distillation via incorporating graphene oxide on PTFE membrane for coking wastewater treatment. Appl. Surf. Sci. 531, 147349 (2020). https://doi.org/ 10.1016/j.apsusc.2020.147349

134. Huang, Q.L., Xiao, C.F., Hu, X.Y., Li, X.F.: Study on the effects and properties of hydrophobic poly(tetrafluoroethylene) membrane. Desalination 277, 187-192 (2011). https://doi.org/10. 1016/j.desal.2011.04.027

135. Deng, L., Li, P., Liu, K., Wang, X., Hsiao, B.S.: Robust superhydrophobic dual layer nanofibrous composite membranes with a hierarchically structured amorphous polypropylene skin for membrane distillation. J. Mater. Chem. A. 7, 11282-11297 (2019). https://doi.org/10.1039/c9ta02662b

136. Abd, G.F., Hamzah, K., Wan Salleh, W.N., Mohamed, H.: Preparation and characterization of PTFE flat sheet membrane: effect of sodium benzoate content. Mal. J. Fund. Appl. Sci. 13, 598601 (2017)

137. Sun, D., Li, B.B., Xu, Z.L.: Preparation and characterization of poly(dimethylsiloxane)-polytetrafluoroethylene (PDMS-PTFE) composite membrane for pervaporation of chloroform from aqueous solution. Korean J. Chem. Eng. 30, 2059-2067 (2013). https://doi.org/10.1007/s11814-013-0147-z

138. Prasanth, R., Shubha, N., Hng, H.H., Srinivasan, M.: Effect of nano-clay on ionic conductivity and electrochemical properties of poly(vinylidene fluoride) based nanocomposite porous polymer membranes and their application as polymer electrolyte in lithium ion batteries. Eur. Polymer J. 49, 307-318 (2013). https:// doi.org/10.1016/j.eurpolymj.2012.10.033

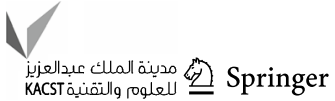


139. Scipioni, R., Gazzoli, D., Teocoli, F., Palumbo, O., Paolone, A., Ibris, N., Brutti, S., Navarra, M.A.: Preparation and characterization of nanocomposite polymer membranes containing functionalized SnO2 additives. Membranes 4, 123-142 (2014). https:// doi.org/10.3390/membranes4010123

140. Ng, L.Y., Chua, H.S., Ng, C.Y.: Incorporation of graphene oxidebased nanocomposite in the polymeric membrane for water and wastewater treatment: a review on recent development. J. Environ. Chem. Eng. 9, 105994 (2021). https://doi.org/10.1016/j.jece. 2021.105994

141. Salah, B., Ayesh, A.I.: Fabrication and characterization of nanocomposite flexible membranes of PVA and $\mathrm{Fe} 3 \mathrm{O} 4$. Molecules (Basel, Switzerland). 26, 1-10 (2020). https://doi.org/10.3390/ molecules26010121
142. Kołodziej, A., Długoń, E., Świętek, M., Ziąbka, M., Dawiec, E., Gubernat, M., Michalec, M., Wesełucha-Birczyńska, A.: A raman spectroscopic analysis of polymer membranes with graphene oxide and reduced graphene oxide. J. Compos. Sci. (2021). https://doi.org/10.3390/jcs5010020

Publisher's Note Springer Nature remains neutral with regard to jurisdictional claims in published maps and institutional affiliations. 